\title{
Spasmodic Dysphonia: Description of the Disease and Associated Neurologic Disorders
}

\author{
Disfonia Espasmódica: Descrição da Doença e dos Distúrbios \\ Neurológicos Associados
}

\author{
Marina Serrato Coelho*, Evaldo Macedo**, Marcela Schmidt Braz de Oliveira***, Paulo Lobo****, \\ Andréa Thomaz Soccol*****, Heloisa Nardi Koemer*. \\ * Resident Physician in the Department of Otorhinolaryngology, HC-UFPR. \\ ** Doctor. Physician in the Department of Otorhinolaryngology, HC-UFPR. \\ **** Intern in the Department of Otorhinolaryngology, HC-UFPR. \\ ***** Physician. \\ ****** Otorhinolaryngologist. \\ Instituition: Hospital de Clinicas, Federal University of Parana \\ Curitiba / PR - Brazil. \\ Mail Address: Marina Serrato Coelho - Rua Francisco Juglair, B 298301 - Curitiba / PR - Brazil - Zip code: 81200-230 - Telephone: (+55 41) 3360-1800 - E-mail: \\ ma.serrato@hotmail.com \\ Article received in October 1, 2009. Article accepted in April 21, 2010.
}

\section{SUMMARY}

Introduction:

Objective:

Method:

Results:

Conclusion:

Keywords:

\section{RESUMO}

Introdução:

Objetivo:

Método:

Resultados:

Conclusão:

Palavras-chave:
Spasmodic dysphonia (SD) is a problem that affects speech and vocalization, one of the most devastating disorders of oral communication. It is characterized by vocal quality tensaestrangulada, harshly and / or interspersed with abrupt vocal attack and a great tension in the vocal tract. The etiology of spasmodic dysphonia is unclear. Some authors point to psychogenic causes, neurological or even unknown. To assess the prevalence of muscular dystonias and other neurological symptoms in patients with ED. A retrospective study of 10 cases with diagnosis of ED for symptoms and neurological disorders associated.

There was a significant predominance of the disease in females (9:1). The average age of onset of symptoms was 32 years, ranging between 14 and 60 years. The mean disease duration was 10 years. Among the patients, $87.5 \%$ had a diagnosis of disorders of movement made by a neurologist, including orofacial dystonias (50\%), essential tremor (50\%) and spastic paraparesis (12\%).

The presence of movement disorders followed almost all cases of spasmodic dysphonia. More studies are needed to clarify the pathophysiological basis of disease.

neuromuscular diseases, voice disorders, dysphonia.

A disfonia espasmódica (DE) é um problema que afeta a fala e a vocalização, sendo uma das mais devastadoras desordens da comunicação oral. É caracterizada por qualidade vocal tensaestrangulada, áspera e/ou entrecortada, com ataque vocal brusco e grande tensão no aparelho fonador. A etiologia da disfonia espasmódica não é clara. Alguns autores apontam para causas psicogênicas, neurológicas ou até desconhecidas.

Avaliar a prevalência de distonias musculares e outros sintomas neurológicos nos pacientes com diagnóstico de disfonia espasmódica.

Estudo retrospectivo de 10 casos com diagnóstico de disfonia espasmódica quanto a sintomas e desordens neurológicas associadas.

Houve franca predominância da doença no sexo feminino (9:1). A idade média do início dos sintomas foi de 32 anos, variando entre 14 e 60 anos. O tempo médio de evolução da doença foi de 10 anos. Dos pacientes avaliados, $87,5 \%$ tinham diagnóstico de distúrbios do movimento feito por neurologista, entre eles distonias orofacias (50\%), tremor essencial (50\%) e paraparesia espástica (12\%).

A presença de desordens do movimento acompanhou quase que a totalidade os casos de disfonia espasmódica. Mais estudos são necessários a fim de esclarecer a base fisiopatológica da doença. doenças neuromusculares, distúrbios da voz, disfonia. 


\section{INTRODUCTION}

Spasmodic dysphonia (SD) is a rare voice disorder caused by a focal dystonia of laryngeal muscles (1). Dystonia can be defined as an involuntary movement disorder characterized by sustained muscle contractions, determining twisting motions and / or abnormal posture. Among the group of diseases characterized by focal dystonia may not cited: Registrar of cramp, spasmodic torticollis, blepharospasm and spasmodic dysphonia (laryngeal dystonia) (2).

Spasmodic dysphonia most often affects women and typically begins at about age 30 (3). Spasmodic dysphonia may present in two forms: adductor spasmodic dysphonia that this is the most common form of presentation of the disease and manifests with voice tensaestrangulada (intense closure of the larynx) and another, much rarer and abduction characterized by intermittent episodes of breathiness or aphonia (difficulty in closing the vocal cords), resulting in air escape during phonation. Can still be found in some patients, an adductor-abductor type combined (4).

The etiology of spasmodic dysphonia is not yet well understood, as well as other forms of focal dystonia. Some authors associate these disorders with psychological disorders, neurological or traumatic (5).

This article aims to assess the prevalence of muscular dystonias and other neurological symptoms in patients with spasmodic dysphonia, whereas a higher incidence of neurological disorders in these patients may corroborate the hypothesis of a neurological origin as etiological basis for spasmodic dysphonia.

\section{MetHod}

This study followed the regulations of the ethics committee of the HC-UFPR (Registration at ZIP CODE / HC 1778.195/2008-09).

Were included in the study patients with clinical diagnosis of spasmodic dysphonia and laryngoscopic followed at the otolaryngology outpatient clinic of the Hospital de Clinicas, UFPR.

Patients were evaluated using a questionnaire regarding spasmodic dysphonia and associated symptoms, and dystonia and other neurological symptoms.

Were considered as carriers of other neurological patients who have had previous diagnosis by a neurologist.
A review was conducted of medical records (ENT and neurological) and review of literature on the subject.

\section{RESULTS}

We evaluated 10 patients with spasmodic dysphonia. Of these, eight responded to the questionnaire. There was a significant predominance of females (9:1).

The average age of onset of symptoms was 32 years, ranging between 14 and 60 years. The mean duration of symptoms was 10 years.

All eight patients reported worsening of symptoms over the years.

In all cases, patients were defined as occupying a position of responsibility in the family or work. In $50 \%$ of cases there were reports of emotional stress and $25 \%$ of mood swings.

Seven of eight patients underwent injection of botulinum toxin, a significant improvement in 100\% of cases.

As for the evaluation of movement disorders, all eight had any complaints, and seven (87.5\%) were diagnosed with disorders of movement made by a neurologist, including orofacial dystonias (50\%), essential tremor (50\%), paraparesis Spastic (12\%). A subjective deterioration of writing was reported by three patients (37\%).

\section{DISCUSSION}

According to literature data spasmodic dysphonia it is a disease that affects mainly women. This same data was found in our study, in which $90 \%$ of the sample was composed of women $(3,4)$.

Characteristically spasmodic dysphonia is considered idiopathic, with a disorder in which the voice is affected by uncontrollable contractions of laryngeal muscles. Often the symptoms are confused with other behavior, since this disorder is exacerbated by stress, fatigue or compensatory maladaptive habits and altered emotional states.

Anyway, the etiology of ED theme is still not fully clarified. Some support the hypothesis that spasmodic dysphonia can treat himself to a disorder of psychogenic basis (2).

In this study, there were reports of emotional stress in $50 \%$ of cases and mood fluctuations by $25 \%$. In another 
study $21 \%$ of patients associated the onset of symptoms of dysphagia with some emotional disturbance (5). Liu et al. showed higher levels of anxiety, depression and somatization disorders among patients with spasmodic dysphonia compared with normal controls. In this study, the emotional state and quality of life were assessed after treatment with botulinum toxin performed and the result showed an improvement in these variables after treatment. Thus the authors suggest that the emotional symptoms of patients with spasmodic dysphonia are mainly secondary to the voice disorder (6). In our data by AminofF et al. none of the patients with spasmodic dysphonia studied had documented psychiatric disorders (7).

Currently, some authors have raised the hypothesis that spastic dysphonia is a focal laryngeal dystonia due to dysfunction of the basal ganglia and many are the focal dystonias that may manifest itself next to her as blepharospasm, spasmodic torticollis and cramping of the Registrar (8).

The article quoted by Behlau Robe (1990) (9) shows changes in the electromyographic tracings of $90 \%$ of a group of 10 patients with spastic dysphonia. This study represents a milestone in the evolution of the concept of spastic dysphonia, and strongly directed attention from researchers concerned for the nature of neurological disease.

Another study suggests that the origin of spasmodic dysphonia can be in the nervous system is accomplished by Kosaki et al. The authors performed histological analysis of the recurrent laryngeal nerve in patients with spasmodic dysphonia compared with controls and noted a higher percentage of nerve fiber bundles analyzed in patients with spasmodic dysphonia compared with normal controls (10).

Aminoff et al. analyzed a sample of 12 patients of whom $50 \%$ had other neurological disorders in addition to spasmodic dysphonia, including: postural tremor, dyskinesia bucolingual, blepharospasm and spasmodic torticollis (7).

Other authors studied 168 patients with diagnosis of spasmodic dysphonia and, relative to other coexisting neurological conditions, $11 \%$ had cramp Registrar of essential tremor and $26 \%$, compared with only $4 \%$ of the control group $(\mathrm{P}=0.0001)(5)$.

In our study, $87.5 \%$ of patients had a diagnosis of movement disorders neurologist made by, among them: orofacial dystonia (50\%), essential tremor (50\%), and spastic paraparesis (12\%). A subjective deterioration of writing was reported by three patients (37\%).
Regarding treatment modalities, there is no evidence showing the effectiveness of speech therapy or psychotherapy in relieving the symptoms of patients with spasmodic dysphonia. Conduct these strategies can improve the effectiveness of other treatments to reduce hyperfunctional voice behaviors (11).

In 1988, BuITZER et al. reported the use of botulinum toxin A for treatment of patients with spasmodic dysphonia. Since then the therapy has become the mainstay in the treatment of vocal disorder (12).

Botulinum toxin A acts by decreasing the force of muscular contraction of the vocal cords by interfering with the release of acetylcholine at the neuromuscular junction. This reduces the effects of partial paralysis of adductor spasm in vocal production. This effect lasts on average three months, after which the new application is required (13).

In our study $100 \%$ of patients treated with botulinum toxin injection showed significant improvement. Our assessment of the patient's improvement was made subjectively by the patient's opinion, as CASSERLY et al. (14) believe it is an appropriate way to evaluate the outcome of treatment, since it is not curative, but rather for symptomatic relief.

Butzzer et al. published a study with a sample of 900 patients with spasmodic dysphonia treated with botulinum toxin over 12 years of follow up. In this study patients with adductor dysphonia had an average recovery of $90 \%$ of normal function with mean duration of 15.1 weeks. Among patients with disorders of the abductors was an average recovery of $66 \%$ with duration of 10.5 weeks (15). Other studies have also shown satisfactory results with botulinum toxin $(16,17$, and 18).

Multiple surgical procedures have been proposed for the treatment of spasmodic dysphonia ranging from recurrent laryngeal nerve section until the thyroplasty type II. But most of these procedures fail to answer the long term and do not offer great advantages for toxin therapy (19, 20, and 21).

\section{CONCLUSION}

In our study the presence of movement disorders that followed nearly all cases of spasmodic dysphonia. Regarding the presence of associated psychiatric disorders is not possible for this study establish a relationship with spasmodic dysphonia, whereas mood disorders have high prevalence in the general population. Treatment with botulinum toxin has temporary results, but 
satisfactory, and are the main therapeutic option today. More studies are needed to clarify the pathophysiological basis and the association between these disorders, as we find more satisfactory therapy if an exact etiology is revealed.

\section{BIBLIOGRAPHICAL REFERENCES}

1. Klotz DA, Maronian NC, Waugh PF, et al. Findings of multiple muscle involvement in a study of 214 patients with laryngeal dystonia using fine-wire electromyography. Ann Otol Rhinol Laryngol. 2004, 113(8):602-12.

2. Dias FMV, et al. Distonia primária e transtorno obsessivocompulsivo. J Bras Psiquiat. 2007, 56: 34-38.

3. Sulica L. Contemporary management of spasmodic dysphonia. Curr Opin Otolaryngol Head Neck Surg. 2004, 12(6):543-8.

4. Ludlow CL, Adler CH, Berke GS, et al. Research priorities in spasmodic dysphonia. Otolaryngol Head Neck Surg. 2008, 139(4):495-505.

5. Schweinfurth JM, Billante M, Courey MS. Risk factors and demographics in patients with spasmodic dysphonia. Laryngoscope. 2002, 112(2):220-3.

6. Liu CY et al. Emocional syntoms are secondary to the voice disorder in patients with spasmodic dysphonia. Gen Hosp Psychiatry. 1998, 20(4):255-9.

7. Aminoff MJ, Dedo HH, Izdebski K. Clinical aspects of spasmodic dysphonia. J Neurol Neurosurg Psychiatry. 1978, 41(4):361-5.

8. Dauer WT, Burke RE, Greene P et al. Current concepts on the clinical features, etiology and management of idiopatic cervical dystonia. Brain. 1998, 121:547-560.

9. Behlau M. O Melhor que Vi e Ouvi: atualização em laringe e voz. Revinter. 1998; 88-97.

10. Kosaki H, Iwamura S, Yamazaki I. Histologic study of the recurrent laryngeal nerve in spasmodic dysphonia. Otolaryngol Head Neck Surg. 1999, 120(1):129-33.
11. Murry T, Woodson GE. Combined-modality treatment of adductor spasmodic dysphonia with botulinum toxin and voice therapy. J Voice. 1995, 9(4):460-5.

12. Blitzer A, Brin MF, FahnS, Lovelace RE. Localized injections of botulinum toxin for the treatment of focal laryngeal dystonia (spastic dysphonia). Laryngoscope. 1988, 98(2):193-7.

13. Cannito MP, Woodson GE, Murry T, Bender B. Perceptual analyses of spasmodic dysphonia before and after treatment. Arch Otolaryngol Head Neck Surg. 2004, 130(12):1393-9.

14. Casserly P, Timon C. Botulinum toxin A injection under electromyographic guidance for treatment of spasmodic dysphonia. J Laryngol Otol. 2008, 122(1):52-6.

15. Blitzer A, Brin MF, Stewart CF. Botulinum toxin management of spasmodic dysphonia (laryngeal dystonia): a 12-year experience in more than 900 patients. Laryngoscope. 1998, 108(10):1435-41.

16. Kimaid PA, Quagliato EM, Crespo NA et al. Laryngeal electromyography in movement disorders: preliminary data. Arq Neuropsiquiatr. 2004, 62(3A):741-4.

17. Larrosa F, Idígora A, Aguilar F, Riera L, Martí MJ, Valls J. Results of using botulism toxin in the treatment of spasmodic dysphonia. Acta Otorrinolaringol Esp. 2002, 53(1):27-31.

18. Damrose JF, Goldman SN, Groessl EJ, Orloff LA. The impact of long-term botulinum toxin injections on symptom severity in patients with spasmodic dysphonia. J Voice. 2004, 18(3):415-22.

19. Koufman JA, Rees CJ, Halum SL, Blalock D. Treatment of adductor-type spasmodic dysphonia by surgical myectomy: a preliminary report. Ann Otol Rhinol Laryngol. 2006, 115(2):97-102.

20. Chan SW, Baxter M, Oates J, Yorston A. Long-term results of type II thyroplasty for adductor spasmodic dysphonia. Laryngoscope. 2004, 114(9):1604-8.

21. Ludlow CL. Treatment for spasmodic dysphonia: limitations of current approaches. Curr Opin Otolaryngol Head Neck Surg. 2009, 17(3):160-5. 